\title{
Community Policing Is A Study In South Sulawesi
}

\author{
La Ode Husen ${ }^{1,}$ Said Sampara ${ }^{2}$, Syamsuddin Pasamai ${ }^{3}$ \\ ${ }^{1,2,3}$, Law of Faculty, Muslim University Of Indonesia, Makassar
}

\begin{abstract}
Community policing has aimed to restore the legitimacy of the police. Not only must the police have legitimacy to win public cooperation, but also a legitimate police institution fosters more widespread obedience of the law itself. community policing can improve citizen perceptions of the police. The development of the function of policing oriented to the community it serves as well as providing access to services in an open, humane, and responsive.
\end{abstract}

\section{Introduction}

It is universally defined as the role of law enforcement police (law enforcement officer) and the maintenance of order (order maintenance). Duties and functions in real terms are yet to be played, as expected. Social and political dynamics in Indonesia, especially during the New Order era, led to the Police co-opted to the political interests of the rulers. ${ }^{i}$ The unification of the police in the military organization cause impress militarized police. Police personnel were involved in the current armed forces that evolved into a tool to preserve the power of the New Order government. Police have antagonistic role toward people who see it as an enemy because it does not protect the public but only to serve the ruler. Human rights violations are common in performing the task. Police position that is structurally shelter under the Armed Forces allows intervention in their role as law enforcers.

Today, the Police still many highlights in terms of quality of performance. Indonesian National Police (INP) is often described as a highly corrupt, arrogant, unprofessional, not democratic, and not independent. Limitations of the quality and quantity of human resources as well as issues related to cultural institutions, budget and finance, facilities and equipment, management and responsibility is still widely encountered in the development of police duties. Although reforms have been going on in the police force since the issuance of MPR Decree No. X / MPR / 1998 on Principles of Reform Development and Instruction President of the Republic of Indonesia Number 2 of 1999 on the policy measures the separation of the Police of the Armed Forces is in fact the appearance (performance) Police have not shown changes significantly.

Police as many law enforcement officers under the spotlight of his inability to perform basic tasks of Police as protectors and servants of the people, the maintenance of social order, as well as law enforcement. Personnel and Police institutions face major problems related to integrity, empowerment, transparency, competence, commitment, consequently, cooperation, and accountability is a basic perinsip make INP professional, independent, and democratic. Community policing has aimed to restore the legitimacy of the police. Not only must the police have legitimacy to win public cooperation, but also a legitimate police institution fosters more widespread obedience of the law itself. community policing can improve citizen perceptions of the police. ${ }^{\text {ii }}$ Nonetheless, Meliala classifies policing professionals (professional policing) as a type of conventional policing because it is often identified with the reactive policing. ${ }^{\text {iii }}$ Professionals who are meant in this activity is the formation of a positive attitude and responsibility for institutional personnel and the Police to do its job properly and ethically, to give "added value", causing satisfaction and comfort to the people or parties related to the duties and functions of the Police. Police position as protector, and a public servant, the keeper of social order and law enforcement can not be executed properly due to limited budget and finance, the quantity and quality of human resources, facilities and equipment, professionalism, and independence. In addition, the role of the Police yet optimal because of the poor public support for the duties and functions of the Police.

On the other hand, one of the positive effects of the reform era is a growing awareness of critical community. Society no longer be passive in the affairs concerning the organization of state power as the past. Society has now more aware of the rights attached to him, it is, recognized in Law Law No.2 / 2002 on the Police as stated in the preamble section menimbangan Letter $b$ ", That the maintenance of security in the country through the implementation efforts of the police function includes the maintenance of security and public 
order, law enforcement, protection, shelter, and service to the community carried out by the Police of the Republic of Indonesia as an instrument of state who is assisted by the public by upholding human rights. "this recognition will be relied upon by the public to demand and collect public service of the whole apparatus of delivery of state, not the exception of police officers. South Sulawesi is a true pioneer of community policing in Indonesia. The formation of groups concerned by the public security and order Kalba Group (abbreviation of the name of three villages namely Desa Kaloling, Lajoa, and Bajiminasa) in Bantaeng on July 9, 1999 to be the forerunner to the implementation of community policing models in formal in Indonesia. Group success brilliantly Kalba awareness about a thousand criminal and deviant behavior over the three years of its existence has encouraged the spread of the application of community policing in South Sulawesi.

In its function as a social control, Group Kalba exerting pressure (presure) by visiting the deviant group to give themselves and be aware of his actions. Decision-making sanctions against the perpetrators decided by the meeting discussed the steps to be taken to resolve the problem.

\section{Issues}

What is the relationship between the police competencies, which include, prefesionalisme, independence, as well as models or wake Community Policing.

\section{Research methods}

In terms of objectives, type of research is a research-based evaluation ${ }^{\text {iv }}$ Basic consideration is that this activity is expected to produce a working paper that will be one input to the preparation of policy documents. The next consideration is that the evaluation based research is also based need to see how far a basic national policy in this regard is Act No. 2 of 2002 had been implemented / operationalized, especially in terms of the main tasks of the National Police. In other words, the research can also be interpreted as a policy research.

\section{Discussion}

Police Problems goal achievement is determined by the subject matter consisting of potential, competence, and performance. This section begins with a description of the appreciation of the respondents to the police in South Sulawesi as a reference for potential development, competency and performance for achieving the Police. ${ }^{\mathrm{v}}$
Respondents gave different assessments of the achievement of performance indicators in South Sulawesi majority of respondents provide an assessment of the achievement of performance over the past three years both for the stability of the security category $(53.98 \%)$ and pembeniaan tranquility $(53.76 \%)$. Achievement of other indicators category performance for regular or not been able to generate significant achievement.

Similarly, when compared with the previous period, the achievement indicators is still not able to produce a significant improvement. Fostering stability and tranquility are rated worked well over the past three years, has not been able to produce a significant change compared to the previous period. Potential factors that most influence on the achievement of all performance indicators is a component of human resources (HR). Coaching and human resource development generates significant effect compared to the budget components and infrastructure in achieving the performance of the police. Overall competency factors significantly influenced by the components of professionalism to the achievement of the Police. Component performance factors have different effects on the achievement of performance. Abuse of authority have a significant influence on the stability of community security and orde $(24.21 \%)$, law enforcement $(26.84 \%)$, and human rights and democracy $(25.08 \%)$. This achievement results in providing protection, shelter and community services have not given satisfactory results because it is still a bad discovery service practice $(27.53 \%)$. In awarding the task of peace have given satisfactory results, it's just in practice in person is still going on discriminatory $(27.74 \%)$, which is based on the primordial consideration, money, and social status. Efforts to increase the achievement of performance improvements have been made through a variety of approaches and programs.

Achievement of the performance of the police in Pangkep rated better than the city of Makassar. It can not be separated from the complexity of the problems of Makassar as the capital of South Sulawesi province and the center of trade and services in Eastern Indonesia. The achievement of all indicators over the past three years is considered good, but tranquility coaching $(57.70 \%)$. Overall achievement of the performance of the last three years has shown significant improvement over the previous period.

Effect of potential and competence components of the achievement of the performance, as well as the aspirations of the respondents in Makassar, each influenced by human resources and professionalism. ${ }^{\mathrm{vi}}$ Component performance factors have different effects on the 
achievement performance, respectively abuses have a significant influence on the stability of internal security $(25.9 \%)$, law enforcement $(25.36 \%)$, the fostering of peace $(25.66 \%)$ as well as the enforcement of human rights and democracy $(26.76 \%)$. Poor service determines significantly to the achievement of performance in the provision of protection, and community services (25.76\%). Efforts to improve the rated excellent in the aspect of performance achievement in human rights and democracy for the success of human resource development in Pangkep Police.

Generally described HR component is very dominant influence on all the indicators of achievement of the objectives of Police. Will be described in the partial effect of each component of the budget, human resources and infrastructure in achieving the goals of Police. Budget components in Makassar provides a higher impact on the maintenance of peace $(24.82 \%)$. The main components of the budget impact on achieving the maintenance of internal security in Pangkep (25.96\%). HR component affects the achievement of the objectives, human rights and democracy in Makassar (54.77\%) and Pangkep (51.24\%). Of use of the infrastructure has a major influence on the achievement of internal security maintenance $(31.25 \%)$ in Makassar and the maintenance of peace $(30 \%)$ in Pangkep.

Components professionalism judged to be a key factor in achieving the goals Police competence. Professionalism is indispensable achievement of the objectives of law enforcement in the city of Makassar (52.63\%) and Pangkep (46.90\%). Police professionalism rated unsatisfactory because in some cases in Makassar can not be solved completely. The limited capacity of member of the police in investigating and filing cases cause was the return of the case file by the prosecution. Weakness in the investigation on the case investigation process is still common practice of intimidation and violence.

Independence of the main problem human rights and democracy in Makassar (36.29\%) and law enforcement (27.13\%). Limitations of independence because of the poor understanding of human rights and democracy and limited knowledge of the law in law enforcement duties as a result of the low capacity of moral and emotional intelligence and intellectual capacity constraints and skills of police enforcement. As the members of the police were high school graduates. These limitations could potentially lead to interventions that lead to the abuse of authority and corruption, collusion, and nepotisme.

Implementation of community policing has not been impressive in both areas of research. New policing function generally limited to the maintenance of peace in the city of Makassar
(21.29\%) and Pangkep (35.27\%). Community policing component has not functioned for the achievement of the objectives of other Police. This is due to lack of understanding of the function of policing that has not been made part of the paradigm and policing strategies. Community policing has not been used for the educational process of law, human rights and democracy.

Based on the results of the survey, indepth interviews, covert in-depth interviews and focus group discussions, formulated the policy orientation and indicative program. On the subjectmatter of the budget oriented on (1) the accountability of the planning, management, use and accountability of the budget, and (2) the effectiveness of the use of the budget. Police budget constraints could be addressed among others by leveraging the partnership fund sourced from local authorities, employers, and society. In order to ensure the accountability of receipt and use of funds and to maintain the independence of a particular party intervention, the partnership conducted institutionalized and transparent.

Police receipt effectiveness can be improved through the control of illegal fees receipt and acceptance unofficial legally administered in the form of off-budget funds. This method may be part of efforts to combat abuse of authority and corruption.

Human resources are a key factor in the deployment of the potential factors for the achievement of objectives can be optimized INP oriented policy (1) the objectivity of the recruitment system and (2) the restructuring of the curriculum, the educational system, and coaching. Problems performasi low competence and police personnel and institutional limitations stem from the quality of human resources. Recruitment system which is considered still fraught with corruption so ignore the factor of integrity, interests, talents, and personal capacity has given rise to an arrogant and corrupt police. For that, it is hoped the involvement of other parties / independent institution in the recruitment process, especially in the selection and determination of graduation.

Five-month study period, four-month internship, and one month of rounding known as Pattern 5: 4: 1 is considered too short so as not to effectively generate a reliable police. The informant proposed education with patterns 7: 2: 1 or 9: 1: 1 as an alternative to produce a professional civilian police and democratic. Competency-based curriculum (CBC), which became part of the education system needs to be sharpened through expectations-based approach to curriculum development regions. Some among which highlights the lack of emotional intelligence and morality of police officers tertetentu by tapping on 
the expected formation of faith and devotion and mastery of the socio-cultural dimensions so as to mendinamisasi potential of society, including the preservation of public participation.

Expectations towards cultural mores daan be key to the success of policing in this area. Order-oriented culture "siri na pace" has been widely abandoned by society, especially among the young, including the new NCOs. On the other hand, society in general, especially in rural areas still preserve the culture of "siri na pace" that can lead to a clash of cultures and social conflicts with local communities. This provision and promotion system got the attention of various circles as judged not fully take place in an objective, accountable and functional. Career coaching expected based on merit and achievement system.

Development-oriented infrastructure (1) the provision of basic needs of members and field operations, and (2) the validity of the strategic planning, management, and technology. Police Pangkep is currently fostering an archipelago consisting of 119 islands have no means of sea transport. For guidance, Pangkep Police rely heavily on public assistance, local governments, and South Sulawesi police personnel even personal funds. Updates facilities and infrastructure oriented to the standardization of infrastructure and the development of an integrated data base system with a criminal justice system based on information, communication, technology (ICT).

Components of professionalism be the determining factor in achieving the goals Police competences oriented to (1) the development of integrity and professionalism of personnel, (2) improvement of institutional management, and (3) updating operational skills. Development of integrity and professionalism aimed at internalizing the paradigm of civilian police, morality, and the supremacy of law. It is necessary for improving the welfare of personnel in proportion with other law enforcement officers, followed by the guidance and supervision of the code of conduct and performance of the police.

Improvement of institutional management oriented towards revamping the police station and police management based on competence and quality management systems. To achieve the necessary clarity manajem integrated quality indicator of the performance of institutions. Performance indicators outlined in a concrete institution and become a reference in quality control in an integrated manner. Improved performance of the police in this area can be improved through the decentralization of management to the police as the spearhead leading in service and goal attainment Police. Conditions faced a dilemma in the line of duty, especially facing a brutal and anarchic mass requires legal protection for police personnel. Suggested the need for organizing protection law rights oriented policing the police.

Independence of the personnel and the police institution is realized through (1) the independence of personnel, (2) institutional independence, and (3) operational independence. There is still a culture of "set peace" and the practice of backing the primordial motive and income generation a moral burden for certain police officers to achieve personal independence. Police institution must act proactively and effectively in coaching and management coaching security community, orde, and tranquility. Functions and roles vacated by the police could potentially be used by the military and institutional components of the society so that no independence in the control of internal security and tranquility coaching. Operational independence is sourced from internal intervention of the Police, as well as from government officials / legislative, military, business, and society in the implementation of the duties and authority of the police. Leader / supervisor and regional leaders should be dismissed various forms of interventions. Leader / supervisor and local officials no longer give colution and deposited in the recruitment process and handling the case by the police personnel.

To increase the performance of the Police who have been constrained by abuse of authority, corruption, poor services, discriminatory treatment, the use of discretion that mistakenly respectively mitigated by: (1) monitoring and enforcement, (2) enforcement, (3) the effectiveness of services , (4) democratic policing, and (5) Reinterpretation and standardization of discretionary action. Corruption that could potentially engulf the entire unit of the National Police to "malignant cancer" which undermined trust and image of the national police as well as hamper the achievement of the Police. To be able to cope with the culture of "peace set" or bribery or abuse of authority Police officers can be charged under Section 11 and Section 12 of Law No.20 of 2001 , descrition such actions as acts of corruption. Culture "organize peace" or bribery or abuse of authority fall into corruption. Police personnel who abuse authority does not adequately resolved through sanctions professional ethics but prosecuted. Similarly, people who teribat in "set peace". Both parties (the police and the public) to be prosecuted for corruption are likely to carry an active and transactional. To narrow the chance of corruption, all forms of revenue unofficial / illegal and levies are categorized as acceptance of offbudget funds so that a state revenue.

Poor service due to the management of the bureaucratic (sometimes seem convoluted and nonsensical) and discrimination can be addressed 
by improving the effectiveness and empowerment of the police become the frontline in the service of the Police, the development of the function of policing oriented to the community it serves as well as providing access to services in an open, humane, and responsive. Discrimination patterned primordial and welfare grounds can be addressed through the development of personal integrity and professionalism of the national police, coaching and development of policing in a democratic style, as well as public awareness that give or promise anything to the Police officers as a form of corruption.

\section{Conclusion}

Achieving goals Police last three years is considered good for the stability and development of peace in the city of Makassar and Pangkep. The status of the entire indicator in Pangkep produce a better development than the previous period. Human resource potential of the dominant factor in the achievement of the Police in the city of Makassar and Pangkep. For the competence factor professionalism component becomes the dominant factor in the achievement of the Police. Performance factors have different effects on the achievement of the objectives of Police in Makassar and Pangkep. Components abuse a dominant factor in the achievement of stability of internal security, law enforcement, and human rights and democracy in Makassar. Power abuse problem in achieving the goals of stability internal security, law enforcement, fostering serenity, and protection of human rights and democracy in Pangkep.

\section{Reference}

Babovic, Police brutality or police torture, Policing: An International Journal of Police Strategies \& Management, 2000, Vol.23

Hawdon, James E Ryan, John Griffin, Sean P, Policing Tactics and Perceptions of Police Legitimacy, Journal, Police Quarterly, 2003, Vol.6

Mc. Carty, W. P.Zhao, J., Garland, Brett E., 2007, Occupational stress and burnout between male and female police officers: Are there any gender differences

Montesquieu, 2009, Methodological pluralism and comparative constitutional law, European Constitutional Law Review, Vol. 5,

Tankebe, Justice, Public confidence in the police: Testing the effects of public experiences of police corruption in Ghana, Journal, British Journal of Criminology, 2010, Vol 50

Untung S. Radjab, 2000, Polisi yang Elegan, Intermedia Publishing, Makasar. i See , McCarty, W. P.Zhao, J., Garland, Brett E.Occupational stress and burnout between male and female police officers: Are there any gender differences, 2007,p.673-674.

ii Hawdon, James E Ryan, John Griffin, Sean P, Policing Tactics and Perceptions of Police Legitimacy, Journal, Police Quarterly, 2003, Vol.6, p.469

${ }^{\mathrm{iii}}$ Untung S. Radjab, Polisi yang Elegan, Intermedia Publishing, Makasar, 2000. h.20

iv Montesquieu, methodological pluralism and comparative constitutional law, European Constitutional Law Review, 2009, Vol. 5, p.27

$\checkmark$ Tankebe, Justice, Public confidence in the police: Testing the effects of public experiences of police corruption in Ghana, Journal, British Journal of Criminology, 2010, Vol 50, p.297

${ }^{v i}$ See Babovic', Police brutality or police torture, Policing: An International Journal of Police Strategies \& Management, 2000, Vol.23, p. 376 